\title{
CONCRETIZATION OF LAW: LEGAL FORMS
}

\author{
Xenia Dovgan \\ Academy of Labor and Social Relations, \\ Moscow, Russian Federation
}

\begin{abstract}
Stability and quality of legislation is checked by time. The organic development of law and the elements of the legal system ensures the protection of the fundamental rights and freedoms of a human and a citizen. In the current living conditions, especially in the period of serious epidemiological upheavals, the effectiveness of the adopted legal acts acquires significant value. This is overwhelmingly important during the period of the legislation update. The effectiveness and unity of legal regulation allows to evaluate the framework legislation. We examine the legislative forms of concretization of the framework legislation at different levels of legal regulation. The research methodology is determined by its sources. The use of the formal legal research method allowed us to analyze legal acts within the system. One of the main mechanisms for implementing the framework legislation is concretization, which enhances balancing law-making, law implementation and law enforcement activities. Due to a certain degree of generalization and abstractness alongside with the direction of legal regulation, key messages, defined at the level of the framework act, are being detailed and concretized in the subordinate act. Considering technical and legal factors, we can trace certain uncertainty created by legislator as a means to regulate new social relations and specify them at a subsequent level of legal regulation, taking into account temporary, socio-economic, procedural, ideological and other criteria.
\end{abstract} law enforcement

Key words: framework legislation, concretization in law, certainty, legislation, law-making,

Conflicts of interest. The author declared no conflicts of interest.

Article received 05 July 2020

Article accepted 15 October 2020

\section{For citation:}

Dovgan, X. (2020) Concretization of law: legal forms. RUDN Journal of Law. 24 (4), 864-880. DOI: 10.22363/2313-2337-2020-24-4-864-880.

(C) Dovgan X., 2020.

This work is licensed under a Creative Commons Attribution 4.0 International License

https://creativecommons.org/licenses/by/4.0 


\title{
ЗАКОНОДАТЕЛЬНЫЕ ФОРМЫ КОНКРЕТИЗАЦИИ ПРАВА
}

\author{
К. Довгань \\ Академия труда и социальных отношений, \\ 2. Москва, Российская Федераџия
}

Стабильность и качество законодательства проверяется временем. Органичное развитие права и элементов правовой системы позволяет обеспечить защиту основных прав и свобод человека и гражданина. В условиях модернизации современной жизни, в том числе в период серьезных эпидемиологических потрясений, эффективность принимаемых правовых актов приобретает существенное значение. Особенно это важно в период обновления законодательства. Эффективность и единство правового регулирования позволяет оценить «рамочное» законодательство. Мы рассмотрели законодательные формы конкретизации «рамочного» законодательства на разных уровнях правового регулирования. Методология исследования определена ее источниками. Применение формально-юридического метода исследования позволило проанализировать правовые акты в системе. Одним из основных механизмом реализации "рамочного" законодательства является конкретизация, которая позволяет сбалансировать правотворческую, правореализационную и правоприменительную деятельность. Благодаря определенной степени обобщенности и абстрактности, направлению правового регулирования, заданные на уровне рамочного акта ключевые посылы детализируются, конкретизируются в соподчиненном акте. Индивидуализация общественных отношений способствует правильному применению юридических норм. Если рассмотреть с технико-юридической точки зрения, то можно проследить применение такого средства правового регулирования как «неопределенность», создаваемое законодателетем в целях регулирования новых общественных отношений и конкретизации их на последующем уровне правового регулирования с учетом временных, социально-экономических, процедурных, идеологических и иных критериев. Гибкая форма правого регулирования путем абстрактного способа формулирования норм права используется в рамочных актах, что открывает новые возможности для эффективного правового регулирования.

Ключевые слова: рамочное законодательство, конкретизация в праве, определенность, законодательство, правотворчество, правоприменение

Конфликт интересов. Автор заявляет об отсутствии конфликта интересов.

Дата поступления в редакцию: 05 июля 2020 г.

Дата принятия к печати: 15 октября 2020 г.

\section{Для цитирования:}

Dovgan X. Concretization of law: legal forms // Вестник Российского университета дружбы народов. Серия: Юридические науки. 2020. Т. 24. № 4. C. 864-880. DOI: 10.22363/ 2313-2337-2020-24-4-864-880.

\section{Introduction}

One of the key challenges in the development of the rule of law is improving legislation. The expansion scope of the legal regulation determines modernization of 
technical and legal means. The norms of a general nature, aimed at frequentative implementation, gain particular importance. The need to specify them is determined by law-making, law implementation and law enforcement practice. Legislation, establishing general principles for regulating public relations (framework legislation), determines the further processes of interpretation and concretization. The potential of the "framework" legislation is revealed through concretization. However, the forms of law concretization are not fully understood at the theoretical and practical levels so far.

To consider the concept of frame we refer to T.F. Efremova's explanatory dictionary, which describes the concept of framework. It means limits, boundaries, restrictions in performance. If we turn to the Comprehensive Legal Dictionary, framework laws (also named as skeletal laws, or framework statues) are a special form of legislative acts adopted by parliament, which establish only general principles for regulating a particular sphere (Suharev, et al., 2002). Certain technical and legal instruments set up limits or boundaries in the framework acts. Meanwhile, the connection with subordinate acts that are in correlation is not lost.

In foreign practice, framework legislation issues are within the jurisdiction of federal states. It is worth noting that such acts are common mainly abroad, namely in France, Germany, Spain, Anglo-Saxon countries and their former colonies. "Rahmengesetz", translated from German, is a framework law that regulates a certain area of public relations, but not completely. It defines the basic principles, and concretization is carried out at the level of regions, i.e. Bundesländer (Symanyuk, 2014:108113). The framework laws are based not only on the issues within the joint jurisdiction of the federal state and regional bodies, but also on those within the exclusive jurisdiction of the federal and regional authorities.

Framework legislation implies legislator's right to adopt rules that only outline the boundaries of legal regulation with a high degree of abstraction.

In Anglo-Saxon countries, framework laws are the legal foundation, which sets out basic rights and duties of citizens that define obligations and principles in general ${ }^{1}$. Framework legislation is the foundation of an effective and well-functioning national statistical system (Knut, 2011).

The concept of frame contract is a legal category having been introduced into civil law and being fixed in the Civil Code of the Russian Federation. According to Article 429.1. of the Russian Civil Code, a frame contract is an agreement with open conditions that "defines the general terms for the obligatory relationship of the parties, which can be concretized and specified by them". A frame contract is a type of civil contract. Thus, the legislator enshrined the concept of a frame contract in civil legislation on June 1, 2015 for the first time (Poduzova, 2017:116-118). The relevance to study the framework legislation is determined by its significance for particular legal sciences.

\footnotetext{
${ }^{1}$ Legal Framework Navigating the Web of Laws and Contracts Governing Extractive Industries (2020), available at: https://resourcegovernance.org/sites/default/files/nrgi_Legal-Framework.pdf. (Accessed 19 January 2020).
} 
A framework law is a kind of general act that contains norms-definitions, norms-principles, norms-goals, and presumptions and provides a normative orientation, setting the vector and/or direction of legal regulation in public relations at various levels (international, federal, regional and local) in order to achieve effective results. The potential of the "framework" legislation is revealed through concretization.

In T.F. Efremova's (Efremova, 2000) explanatory dictionary the notion concretize means to give a concrete expression to something, to clarify something. In the legal literature, concretization is understood as a feature of law (Vengerov. 1970), a means of filling the gaps (Lazarev, 2018), an attribute of the legal regulation process (A.F. Cherdantsev, 1974), a logical continuation of the transition issues from uncertainty to certainty (Tikhomirov, 2015).

According to N.A. Vlasenko, the transition "from the uncertainty of the law content to its certainty" (Vlasenko, 2013:34) is due to concretization. N.N. Vopenko believes that "concretization is the result of a law-making or law-enforcement process where the maximum certainty and completeness of the meaning of legal norms became possible due to the means of interpretation, detail, clarification or development of separate elements of norms aimed at accurate and complete legal regulation" (Voplenko, 1976:55).

Depending on the stages of legal regulation and their specific features, M.V. Zaloilo identifies three forms of concretization of legal norms: law-making, law-enforcement and law-interpretation. Law-making concretization is understood as "the activity of authorized bodies aimed at adopting new clarifying legal norms based on the meaning and content of the original legal norms" (Zaloilo, 2019). Lawenforcement concretization is an "individualization of norms in accordance with a specific setting, as applied to a specific subject of legal relations" (Zaloilo, 2014). The law-interpretation concretization is aimed at "clarifying and supplementing the interpretation act process, filling the rule of law with new content" (Zaloilo, 2012).

The issues of spatial and hierarchical concretization have also been the research focus of the Russian scholars. S.S. Alekseev, S.V. Polenina, A.F. Cherdantcev looked at the features of concretization at different stages of legal regulation (Alekseev, 1981; Polenina, 1996; Cherdancev, 1974).

The problem of correlation between the degree of concretization of norms and the hierarchy of sources of law has been addressed by V.A. Tolstik. The author highlights "the straightforward relationship between the degree of generality (abstractness) of legal norms and their hierarchy", while "the legislator should strive not to establish more general norms in subordinate normative acts than in superior ones, and vice versa" (Tolstik, 2008:117).

Yu.G. Arzamasov, V.M. Baranov, S.V. Boshno, V.V. Lazarev, A.F. Nozdrachev, T.A. Pytikova, and V.A. Sivitsky studied hierarchical types of law-making concretization of legal norms. V.A. Sivickij noted that "laws can be concretized by bylaws in case of a corresponding prescription" and necessity in law enforcement (Sivickij, 2008:172-128). However, modern legislation makes it possible to single out other forms of spatial and hierarchical concretization of legal norms. 


\section{Legal forms of spatial concretization}

Spatial concretization exists at the international and domestic levels. The norms contained in international acts are often specified in domestic laws. In the international law, one can come across the acts that apply the concept of framework, for example, the UN Framework Convention on Climate Change, the WHO Framework Convention on Tobacco Control and others. After their ratification, conventions, multilateral, bilateral international treaties or agreements have also a significant impact on national legislations. Model provisions of international acts are specified in the laws of respective state, for example, the Federal Law (hereinafter- FZ) dated May 5, 2014 No. 126-FZ "On Amending Certain Legislative Acts of the Russian Federation in Connection with the Accession of the Russian Federation to the Convention on Civil Law Aspects of International Child Abduction" amended a number of Russian acts on the issues of procedural regulation of abducted children return ${ }^{2}$.

The 1969 Vienna Convention ${ }^{3}$ and the Federal Law "On International Treaties of the Russian Federation" 4 contain the norms that are identical in terms of content, formal and functional features, with the same wording as "Use of Terms" ("ratification", "approval", "acceptance" and "accession") not to mention the coincidence of numbering.

The provisions of international treaties (agreements) are often specified in the national legislation of the Russian Federation. For example, personal law is an element of the well-established principle of the "personal law of an individual". Legal capacity of foreign citizens is determined according to the laws of the country whose citizen a person is, or, in case of a stateless person, by his or her place of residence or country of residence. This principle can be traced in many standard international treaties of the Russian Federation on legal assistance, especially in civil matters, for example, in the agreement between the Russian Federation and the Republic of Estonia on legal assistance and legal relations in civil, family and criminal matters (art. 22) .

\footnotetext{
${ }^{2}$ Federal'nyi Zakon No. 126-FZ ot 05.05.2014 “O vnesenii izmenenii v otdel'nye zakonodatel'nye akty Rossiiskoi Federatsii v svyazi s prisoedineniem Rossiiskoi Federacii k Konvencii o grazhdansko-pravovyh aspektah mezhdunarodnogo pohishcheniya detej"[Federal Law No. 126-FZ "On amendments to certain legislative acts of the Russian Federation in connection with the accession of the Russian Federation to the Convention on Civil Law Aspects of International Child Abduction], available at: http://www.consultant.ru (Accessed 19 May 2020).

${ }^{3}$ Venskaya konvenciya o prave mezhdunarodnyh dogovorov ot 23.05.1969 [Vienna Convention on the Law of Treaties], available at: http://www.consultant.ru (Accessed 19 May 2020).

${ }^{4}$ Federal'nyi Zakon No. 101-FZ ot 15.07.1995 “O mezhdunarodnyh dogovorah Rossiiskoi Federatsii” [Federal Law No. 101-FZ of July 15, 1995 "On International Treaties of the Russian Federation"], available at: http://www.consultant.ru (Accessed 19 May 2020).

${ }^{5}$ Dogovor mezhdu Rossijskoi Federaciej i Estonskoi Respublikoi o pravovoi pomoshchi i pravovyh otnosheniyah po grazhdanskim, semejnym i ugolovnym delam (Podpisan v g. Moskve 26.01.1993) [Agreement between the Russian Federation and the Republic of Estonia on legal assistance and legal relations in civil, family and criminal matters (Signed in Moscow on 01/26/1993)], available at: http://www.consultant.ru (Accessed 19 May 2020).
} 
The Civil Procedure Code of the Russian Federation and the Civil Code of the Russian Federation contain specific provisions (article 399 of the Code of Civil Procedure of the Russian Federation and article 1196 of the Civil Code of the Russian Federation) that the civil and civil procedural legal capacity and legal capacity of foreign citizens and stateless persons are determined by their personal law ${ }^{6}$.

The adverse process can also take place in the legislation when the spatial concretization of national laws is reflected in international norms. Due to rather abstract norms of the framework legislation, standard provisions of particular state rules are specified in international acts. For example, on September 30, 2016, the Government of the Russian Federation approved the "Rules for concluding international treaties of the Russian Federation on the promotion and protection of investments", which is a framework in relation to all Russian standard agreements with foreign states. Under this agreement (according to its form and provisions), Russia signs international agreements with foreign countries where the maximum degree of commonality is concentrated at the level of the Russian government acts. The framework acts of the Russian supreme executive authority declaratively consolidate the main motives, goals, and objectives of international treaties of the Russian Federation.

Thus, spatial concretization can exist in various forms. The impact of international norms on national law is manifested in various ways, for example, when defining the concepts used in a legal act through interpreting certain legal norms or filling in the gaps in law (Halafjan, 2017:29-37). The adverse process is evident when certain provisions of the national legislation of the state are specified in international treaties or agreements. In one of his works Yu.A. Tikhomirov noted that international law "has a large degree of regulatory concentration. Norms-definitions, normsprinciples, norms-goals, collision norms and presumptions determine normative orientation of national norms, setting up the direction of regulation. International norms mainly effect the disposition of national norms. The choice of specific regulators remains with national law" (Tikhomirov, 2002:101-111).

In this case, the norms of international law are a guideline, setting the scope of legal regulation for national legislation, giving freedom to implement and concretize to each state. A high degree of commonality, defining the goals, motives of a legal act, object and orientation of legal regulation, the statement of well-known terms and facts ensure the semantic unity of the subordinate acts. At the same time, the ideological criterion of concretization is observed in national acts.

\footnotetext{
${ }^{6}$ Grazhdanskii kodeks Rossiiskoi Federatsii (chast' tret'ya) ot 26.11.2001 No. 146-FZ [Civil Code of the Russian Federation (part three) of November 26, 2001 No 146-FZ], available at: http://www.consultant.ru (Accessed 20 May 2020).

${ }^{7}$ Postanovlenie Pravitel'stva RF ot 30.09.2016 No. 992 "O zaklyuchenii mezhdunarodnyh dogovorov Rossiiskoi Federatsii po voprosam pooshchreniya i zashchity investicii" [ Decree of the Government of the Russian Federation of September 30, 2016 N 992 "On the conclusion of international treaties of the Russian Federation on the promotion and protection of investments"], available at: http://www.consultant.ru (Accessed 20 May 2020).
} 


\section{Legal forms of hierarchical concretization}

Hierarchical concretization exists at the legislative and subordinate levels of legal regulation. Each state has its own unique legal system, history and culture, which determine how issues are resolved between the federal center and its constituents (Senjakin, 2007; Strashun, 2000). The Constitution of the Russian Federation (Articles 71-73) does not mention the framework laws. However, the examples of framework legislation can be found in federal and regional legislation.

In the domestic legal system, at its federal level, framework legislation can exist in the form of federal constitutional law, federal law, national programs, and strategies, where abstract norms (standard provisions) are specified in other federal acts, for example, federal law. Concretization of the national project program "Safe and high-quality roads" , federal target program "Improving Road Safety in 20132020 "' is carried out in a number of federal acts, namely, in federal laws on the federal budget for the corresponding period, the Federal Law "On Road Traffic Safety", the Federal Law "On Roads and Road Activities in the Russian Federation and on Amending Certain Legislative Acts of the Russian Federation", Federal Law "On the Organization of Traffic in the Russian Federation and on Amending Certain Legislative Acts of the Russian Federation" and others.

A framework law can be concretized not only in the subordinate law, but also in the acts of executive authorities. Thus, the federal law "On additional measures of state support for families with children" 10 defines the main provisions of an additional measure of support for families with children, as maternal (family) capital. Departmental acts are adopted at the level of the Russian Federation Government and relevant bodies that clarify and supplement Federal Law No. 256. For example, Decree of the Government of the Russian Federation of April 9, 2020 No. 474 "On approval of the rules for making monthly payments to families entitled to maternal (family) capital"11, Order of the Ministry of Labor and Social Protection of the Russian Federation

\footnotetext{
${ }^{8}$ Pasport nacional'nogo proekta "Bezopasnye i kachestvennye avtomobil'nye dorogi" (utv. prezidiumom Soveta pri Prezidente RF po strategicheskomu razvitiyu i nacional'nym proektam, protokol No. 15 ot 24.12.2018) [Passport of the national project "Safe and High-Quality Roads" (approved by the Presidium of the Presidential Council for Strategic Development and National Projects, Protocol No. 15 of 12.24.2018)], available at: http://www.consultant.ru (Accessed 20 May 2020).

${ }^{9}$ Postanovlenie Pravitel'stva RF No. 864 ot 03.10 .2013 "O federal'noi celevoi programme "Povyshenie bezopasnosti dorozhnogo dvizheniya v 2013-2020 godah" [Decree of the Government of the Russian Federation No. 864 of 03.10.2013 "On the federal target program" Improving road safety in 2013-2020], available at: http://www.consultant.ru (Accessed 20 May 2020).

${ }^{10}$ Federal'nyi zakon No. 256-FZ ot 29.12.2006 "O dopolnitel'nyh merah gosudarstvennoi podderzhki semej, imeyushchih detej" [Federal Law No. 256-FZ of December 29, 2006 "On Additional Measures of State Support to Families with Children"], available at: http://www.consultant.ru (Accessed 20 May 2020).

${ }^{11}$ Postanovlenie Pravitel'stva RF No. 474 ot 9.04.2020 "Ob utverzhdenii Pravil osushchestvleniya ezhemesyachnoi vyplaty sem'yam, imeyushchim pravo na materinskii (semeinyi) capital" [Decree of the Government of the Russian Federation No. 474 of April 9, 2020 "On approval of the rules for making monthly payments to families entitled to maternal (family) capital"], available at: http://www.consultant.ru (Accessed 20 May 2020).
} 
of August 2, 2017 No. 606n "On approval of the Rules for submitting an application for disposal of funds (part of funds) of maternal (family) capital and a list of documents necessary for exercising the right to dispose of funds of maternal (family) capital"12 ).

By creating an invisible framework of legal regulation, framework legislation creates prospects for further concretization; this is either directly stated in the law or follows from the nature of legal relationship. The boundaries of the framework legislation can be determined by the level of political, economic, social, historical and cultural development of the state.

The beginning of 2020 will go down in history as a period of a serious pandemic of coronavirus infection that has affected all areas of our society. The area of jurisprudence is no exception. Presidential Decree dated 02.04.2020 No. 239 "On measures to ensure the sanitary and epidemiological well-being of the population in the Russian Federation in connection with the spread of a new coronavirus infection (COVID-19)"13 granted authority to senior officials of constituent entities to determine the system of restrictive measures and other measures to prevent the spread of the new coronavirus infection (COVID-19) in the territory of the corresponding constituent entity of the Russian Federation.

This Decree outlined the general framework for further regulation of issues at the level of constituent entities of the Russian Federation. On the one hand, the Decree laid the foundation for legal regulation of measures to ensure the sanitary and epidemiological well-being of the population, defined the boundaries for further regulation of issues at the regional level, and on the other hand, it created the possibility for the constituent authorities to adopt and amend existing regional acts, based on the provisions of this Decree but taking into account specific features of the region, sanitary and epidemiological situation, and characteristics of the new coronavirus infection (COVID-19). Along with relevance and significance of this Decree, it is also of great interest in terms of legal science.

Due to certain generalization and abstractness and the choice of legal regulation at the level of Presidential Decree, it is possible to take operational measures at the level of constituent entities of the Russian Federation. Such choice of the means

\footnotetext{
${ }^{12}$ Prikaz Ministerstva truda i social'noi zashchity RF No. 606n ot 2.08. 2017 “Ob utverzhdenii Pravil podachi zayavleniya o rasporyazhenii sredstvami (chast'yu sredstv) materinskogo (semeinogo) kapitala i perechnya dokumentov, neobhodimyh dlya realizacii prava rasporyazheniya sredstvami materinskogo (semejnogo) kapitala" [Order of the Ministry of Labor and Social Protection of the Russian Federation No. $606 \mathrm{n}$ of 2.08. 2017 "On approval of the Rules for submitting an application for disposal of funds (part of funds) of maternal (family) capital and a list of documents necessary for exercising the right to dispose of funds of maternal (family) capital"], available at: http://www.consultant.ru (Accessed 20 May 2020).

${ }^{13}$ Ukaz Prezidenta RF ot 02.04.2020 № 239 “O merah po obespecheniyu sanitarno-epidemiologicheskogo blagopoluchiya naseleniya na territorii Rossiiskoi Federatsii v svyazi s rasprostraneniem novoi koronavirusnoi infekcii (COVID-19)" [Decree of the President of the Russian Federation of 02.04.2020 No. 239 "On measures to ensure sanitary and epidemiological well-being of the population in the Russian Federation in connection with the spread of a new coronavirus infection (COVID-19)"], available at: http://www. consultant.ru (Accessed 20 May 2020).
} 
of legal regulation defined at the level of the decree of the President of the Russian Federation allows detailing and concretizing the key messages in adopting the interim measures.

From technical and legal points of view, one can trace the use of such a means of legal regulation as "uncertainty" (Vlasenko, 2014), which is deliberately done in order to embrace new public relations and further concretize (Vlasenko, 2008) laws of the constituent entities. In this case, not only the legal properties of concretization are being manifested, but also temporary, spatial, socio-economic, procedural as well as ideological ones. Restrictive measures, based on the sanitary-epidemiological situation and coronavirus infection spread in the regions, can be implemented at different timespans within a month. Such provision is reasonable and essential.

A similar link is evident at the level of joint jurisdiction of the Federation and its constituents. Correlation of federal and regional acts in law enforcement practice raise certain problems, as well as discussions on the doctrine. Problematic issues relate to reproduction (duplication) in the regulatory legal acts of the constituent entities the constitutional norms and federal laws. There is an opinion that federal norms are duplicated in the regulatory legal acts of the constituent entities for convenience of their application (Krokhina, 2001:70-77).

The provisions of laws and acts of ministries are specified at the state level, at the level of public-private institutions and corporations. Federal Law No. 273-FZ "On Combating Corruption" ${ }^{" 14}$ dated December 25, 2008 is a framework law in relation to all state and public-private legal entities. Thus, by decision of the Board of Directors of PAO Gazprom No. 2846 dated November 15, 2016, the Anti-Corruption Policy of PAO Gazprom ${ }^{15}$ was approved.

If we look at implementation of acts of executive authorities in regional subordinate acts, we can say that the doctrine focuses on this issue in the works devoted to departmental lawmaking. According to Yu.G. Arzamasov, the key idea is that departmental rulemaking can be carried out both on a competent and delegated basis (Arzamasov, 2003:120-123). S.V. Boshno and T.A. Pytikova assert that the federal executive bodies most frequently use such form of departmental acts as an order, which is explained by the "historical continuity of the most convenient and proven methods of legal regulation" (Boshno, et al., 2005:10-12). Yu.L. Korabelnikova and Yu.V. Yanin argue that the procedure for preparing and issuing legislative acts is a rather time-consuming process; it is the rule-making activity of the federal executive bodies, with the appropriate competence, that allows to regulate the relevant public relations properly (Korabelnikova, et al., 2019:55-58).

\footnotetext{
${ }^{14}$ Federal'nyi zakon No. 273-FZ ot 25.12.2008 "O protivodeistvii korrupcii" [Federal Law No. 273-FZ of December 25, 2008 "Anti-corruption”], available at: http://www.consultant.ru (Accessed 20 May 2020).

${ }^{15}$ The official site of PAO Gazprom (2020), «Anti-corruption policy of PAO «GAZPROM»», availiable at: https://www.gazprom.ru/f/posts/60/091228/anti-corruption-policy-2016-11-15-ru.pdf.
} 
Excessive formalism does not allow the constituents to decide on the choice of a possible variant of behavior. Framework legislation contributes to regulation of public relations, taking into account the specifics of the relevant circumstances.

The development of modern technology creates such social relations that lack legal regulation. As Yu.A. Tikhomirov notes, "legislative regulation does not keep pace with the development of relations, serves as a means of their delayed regulation, and does not have an outrunning effect" (Tikhomirov, 2015). In this regard, the issue of proactive lawmaking remains relevant, but ambiguous in the doctrine. Some scholars consider it to be a special type of lawmaking realized in creating legal norms, the subject of regulation of which are public relations that were not previously regulated by law (Baranova, 2016:43-45). Other authors believe that the forward reflection of reality is one of the principles of legal regulation (Tikhomirov, Rafalyuk, Khludeneva, 2014; Baranov, 2017).

Proactive lawmaking is not just a legal concept or legal term. It is a lawmaking tool, the use of which involves a particular risk. Proactive lawmaking is an integral part of strategic planning. Legal regulation in accordance with the goals and objectives of strategic regulation can serve as an example of proactive lawmaking, for example, Law of the Republic of Mari El dated March 6, 2008 No. 5-3 "On regulatory legal acts of the Republic of Mari El" (Zaloilo, 2019).

Recently, some regions of this country, such as Volgograd, Voronezh and Tambov regions, the Altai Territory, as well as the Krasnodar Territory, are trying to fill legislative gaps at the Federation level by adopting acts on vesting executive bodies of the constituent entities of the Federation with managerial functions in the field of protection and use of forest stands located on agricultural land. However, there is no common solution to this issue in the legislative activity of the constituent entities. The above functions are carried out either by agricultural authorities, or forestry bodies, or bodies responsible for the use of natural resources with their structural units. And if these powers were consolidated in the jurisdiction of one governing body, it would ensure the land use sustainability, as well as conserve the positive effect of the stands.

There is a law No. 95-ZS dated December 6, 2017 "On ensuring the peace and quiet of citizens in the Altai Territory"16, which has no analogues at the federal level. It speaks about certain independence and initiative in adopting local laws, which is encouraged, however, such laws make up only a small part against the general picture.

More than twenty regions in Russia have their own laws "On beekeeping", which establish the obligations of beekeepers, as well as regulate their rights. Moreover, nomadic maps, apiary placement norms and other mechanisms for the beekeeping industry development were also developed along with the adoption of the law, for

\footnotetext{
${ }^{16}$ Zakon Altaiskogo kraya No. 95-ZS ot 06.122017 goda "Ob obespechenii tishiny i pokoya grazhdan na territorii Altaiskogo kraya" [Law of the Altai Territory No. 95-3S dated December 6, 2017 "On ensuring peace and quiet of citizens in the territory of the Altai Territory"], available at: http://www.consultant.ru (Accessed 20 May 2020).
} 
example, "On Beekeeping"17 in the Altai of December 6, 2010 (No. 110-ZS) ${ }^{18}$. In 2016, the federal "Veterinary rules for maintenance honeybees for the purpose of their reproduction, cultivation, sale and use for pollination of agricultural entomophilous plants and the production of beekeeping" were approved. They establish the requirements for the conditions of keeping honeybees by citizens and legal entities as well as the requirements for implementation of measures for quarantine of bees, mandatory preventive measures and diagnostic studies of bees ${ }^{19}$.

Framework legislation may exist at the level of acts of the head of the constituent entities of the Russian Federation, when they are specified in the acts of regional ministries and departments, for example, the Decree of the Governor of the Altai Territory "On Approval of the Regulation on the Ministry of Construction, Transport, Housing and Communal Services of the Altai Territory" dated December 8, $2016^{20}$. It is a framework act, since it approves the structure and basic powers of the relevant regional ministry. However, regional acts may be concretized in other regional acts as well. If we consider the Order of the Ministry of Regional Development of the Altai Republic No. 301-D dated June17, 2019 "On approval of the procedure for the accumulation of municipal solid waste (including their separate accumulation) in the Republic of Altai and the recognition of the order of the Ministry of Regional Development of the Republic of Altai No. 447-D dated October 30, 2017"21, we can see that its main provisions are specified in the order of the Tariff Committee of the Republic of Altai No. 55-VD dated August 17, 2018 "On establishing standards for the accu-

\footnotetext{
${ }^{17}$ Zakon Altaiskogo kraya No. 110-ZS ot 6.12. 2010 "O pchelovodstve" [The law of the Altai Territory No. 110-3S dated 6.12. 2010 "On beekeeping"], available at: http://www.consultant.ru (Accessed 20 May 2020). ${ }^{18}$ Lel'ko, A. (2018) Pchely v zakone. [Bees in the law]. Bulletin of the agro-industrial complex, 2. Online, availiable at: http://vestnikapk.ru/articles/aktualno/pchely-v-zakone/ (Accessed 25 May 2020).

${ }^{19}$ Prikaz Minsel'hoza Rossii No. 194 ot 19.05.2016 "Ob utverzhdenii Veterinarnyh pravil soderzhaniya medonosnyh pchel $\mathrm{v}$ celyah ih vosproizvodstva, vyrashchivaniya, realizacii i ispol'zovaniya dlya opyleniya sel'skohozyajstvennyh entomofil'nyh rastenii i polucheniya produkcii pchelovodstva" [Order of the Ministry of Agriculture of Russia No. 194 dated 19.05.2016 "On approval of the Veterinary Rules for maintenance of honeybees for the purpose of their reproduction, cultivation, sale and use for pollination of agricultural entomophilous plants and production of beekeeping"], available at: http://www.consultant.ru (Accessed 20 May 2020).

${ }^{20}$ Ukaz Gubernatora Altaiskogo kraya "Ob utverzhdenii Polozheniya o Ministerstve stroitel'stva, transporta, zhilishchno-kommunal'nogo hozyajstva Altaiskogo kraya" ot 8.12.2016 [Decree of the Governor of the Altai Territory "On approval of the Regulation on the Ministry of Construction, Transport, Housing and Communal Services of the Altai Territory" dated December 8, 2016], available at: http://www.consultant.ru (Accessed 20 May 2020).

${ }^{21}$ Prikaz Minregionrazvitiya Respubliki Altaj No. 301-D ot 17.06.2019 “Ob utverzhdenii Poryadka nakopleniya tverdyh kommunal'nyh othodov ( $\mathrm{v}$ tom chisle ih razdel'nogo nakopleniya) na territorii Respubliki Altaj i priznanii utrativshim silu prikaza Ministerstva regional'nogo razvitiya Respubliki Altaj ot 30.10.2017 № 447-D” [Order of the Ministry of Regional Development of the Republic of Altai No. 301-D dated June 17, 2019 "On approval of the procedure for the accumulation of municipal solid waste (including their separate accumulation) in the Republic of Altai and recognition of the order of the Ministry of Regional Development of the Republic of Altai No. 447-D dated October 30, 2017'], available at: http://www. consultant.ru (Accessed 20 May 2020).
} 
mulation of solid municipal waste in the Republic of Altai and recognizing some of the orders of the Tariff Committee of the Republic of Altai repealed"22.

On the other hand, regional acts can also be concretized at the level of regional enterprises, organizations, and corporations. The Decree of the Government of the Altai Territory No. 297 dated July 31, 2019 "On approving the state program of the Altai Territory "Providing the population of the Altai Territory with housing and communal services" characterizes the current state of gas supply and gasification of the Altai Territory. These provisions are concretized at the level of regional establishments, for example, in standards of PAO Gazprom Gas Distribution ${ }^{23}$.

The adverse process is possible as well; acts of regional bodies can be concretized in the acts of the head of a constituent entity of the Russian Federation, for example, the Decree of the Government of the Altai Territory No. 392 dated October 16,2018 "On executive bodies of the Altai Territory" 24 is a framework law in relation to the Decree of the Governor of the Altai Territory "On approval of the Regulation on the inspection of financial, economic and procurement control in the Altai Territory" dated November $13,2018^{25}$.

One can also distinguish the municipal level of the framework law. It can be treated within the same principle as the regional one.

\section{Conclusion}

Legal forms of concretization exist at different levels of legal regulation. Uncertainty in the framework legislation, allows balancing the process of legal regulation with the help of concretization. The level of uncertainty in the framework legislation may vary; it seems to depend on the volume and content of regulated social relations. Through concretization a legal norm gains further development. The boundaries

\footnotetext{
${ }^{22}$ Prikaz Komiteta po tarifam Respubliki Altaj No. 55-VD ot 17.08.2018 “Ob ustanovlenii normativov nakopleniya tverdyh kommunal'nyh othodov na territorii Respubliki Altaj i priznanii utrativshimi silu nekotoryh prikazov Komiteta po tarifam Respubliki Altai" [Order of the Tariff Committee of the Republic of Altai No. 55-VD dated August 17, 2018 "On Establishing Standards for the Accumulation of Solid Municipal Wastes in the Republic of Altai and Recognizing some of the Orders of the Tariff Committee of the Republic of Altai repealed"], available at: http://www.consultant.ru (Accessed 20 May 2020).

${ }^{23}$ Postanovlenie Pravitel'stva Altaiskogo kraya No. 297 ot 31.07.2019 "Ob utverzhdenii gosudarstvennoi programmy Altaiskogo kraya "Obespechenie naseleniya Altaiskogo kraya zhilishchno-kommunal'nymi uslugami" [Decree of the Government of the Altai Territory No. 297 of July 31, 2019 "On approval of the state program of the Altai Territory" Providing the population of Altai Territory with housing and communal services"], available at: http://www.consultant.ru (Accessed 20 May 2020).

${ }^{24}$ Postanovlenie Pravitel'stva Altaiskogo kraya ot 16.10.2018 № 392 “Ob organah ispolnitel'noi vlasti Altaiskogo kraya" [Decree of the Government of the Altai Territory of October 16, 2018 No. 392 "On Executive Bodies of the Altai Territory"], available at: http://www.consultant.ru (Accessed 20 May 2020).

${ }^{25}$ Ukaz Gubernatora Altaiskogo kraya "Ob utverzhdenii Polozheniya ob inspekcii finansovoekonomicheskogo kontrolya i kontrolya v sfere zakupok Altaiskogo kraya" ot 13.11. 2018 [Decree of the Governor of AK "On approval of the Regulation on the inspection of financial and economic control and procurement control in the Altai Territory" dated November 13, 2018], available at: http://www.consultant.ru (Accessed 20 May 2020).
} 
of concretization should take into consideration temporary, socio-economic, procedural, ideological and other criteria. Concretization contributes to a detailed regulation of the framework legislation and to filling gaps.

Within the framework of international legal regulation, framework legislation can act as an international act, as well as a national one. The provisions of an international act may be concretized in national legislation if ratified. Meanwhile, the provisions of national law may be disclosed in international treaties or agreements.

Federal laws also contain framework laws. Standard provisions from federal laws, federal constitutional laws can be concretized in other acts, such as federal laws, ministerial acts (departments), regional acts, acts of state corporations (enterprises), etc. Acts of the Government of the Russian Federation and relevant ministries (departments) can also be framework.

Framework legislation also exists at the level of constituent entities of the Russian Federation. Regional acts may be framework in relation to federal acts due to the proactive law-making development. Regional acts may be framework in relation to other regional acts and acts of regional establishments. Similarly, acts of the head of the region may have the signs of a framework act. Regional authorities formally have broad powers to adopt laws, including the sphere of exclusive jurisdiction, however, in practice, they adhere to the policy of predominant concretization of federal legislation and do not adopt laws in exclusive jurisdiction very often.

The right to proactive law-making will have practical significance when the problem of uncertainty of the legal regulation boundaries of the constituent entities of the Russian Federation is solved. According to paragraph 1, article 12 of the Federal Law No. 119-FZ of June 26, 1999 (repealed, but this provision is still relevant for current legislation as it correlates with the federal law now in force) on issues related to the subjects of joint jurisdiction of the Russian Federation and its constituent entities, "federal laws are issued to define the basis (general principles) of legal regulation, including the principles of delimitation of powers between federal bodies of state power and bodies of state power of the constituent entities of the Russian Federation; federal laws are also aimed at realization of powers of federal executive bodies."

Framework legislation defines the general framework of a legal act for further regulation of public relations. On the one hand, it defines the foundations of legal regulation, and on the other, it creates the possibility of differentiation of subordinate acts, based on the specific features of social relations. Due to a certain degree of generalization and abstractness and the choice of the direction of legal regulation at the level of the law there is an opportunity for taking operational measures at the level of constituent entities of the Russian Federation. The key provisions of the framework law are concretized in the legislation of the subordinate acts.

The legislator has the right to adopt regulations that just outline the boundaries of legal regulation with the help of a high degree of abstraction in order to $\mathrm{em}$ brace new social relations and concretize at a subsequent level of legal regulation, taking into account certain criteria. A flexible form of legal regulation through an ab- 
stract way of formulating the rules of law is used in framework acts; this opens new opportunities for effective legal regulation.

\section{References / Библиографический список}

Alekseev, S.S. (1981) Obshchaya teoriya prava: $v 2 t$. [General theory of law: in 2 volumes]. T. I. Moscow, Yuridicheskaya literature Publ. (in Russian).

Алексеев С.С. Общая теория права: в 2 т. Т. І. М.: Юрид. лит., 1981. 361 с.

Arzamasov, Ju.G. (2003) Vedomstvennoe normotvorchestvo: ponyatie i funkcii. [Departmental rule-making: concept and functions]. Public Administration. 4(24), 120-123. (in Russian).

Арзамасов Ю.Г. Ведомственное нормотворчество: понятие и функции // Государственная служба. 2003. № 4(24). С. 120-123.

Baranov, V.M. (2017) Ocherki tehniki pravotvorchestva. Izbrannye trudy: monografija. [Essays on the technology of lawmaking. Selected Works: Monograph]. Moscow, Justice Publ. (in Russian).

Баранов В.М. Очерки техники правотворчества. Избранные труды: монография. М.: Юстиция, 2017. 585 с.

Baranova, M.V. (2016) Anticipatory law-making in the legal system of modernity. Bulletin of the Saratov State Law Academy. (1), 43-45. (in Russian).

Баранова M.B. (2016) Опережающее правотворчество в правовой системе современности // Вестник Саратовской государственной юридической академии. № 1 . 2016. C. 43-45.

Boshno, S.V., Pytikova, T.A. (2005) Prikaz: normativnyi ili pravoprimenitel'nyi akt? [Order: regulatory or enforcement act?]. Lawyer. (10), 10-12. (in Russian).

Бошно C. B., Пытикова Т.A. Приказ: нормативный или правоприменительный акт? // Юрист. 2005. № 10. С. 10-12.

Cherdancev, A.F. (1974) Pravovoe regulirovanie i konkretizaciia prava. [Legal regulation and concretization of law]. Application of Soviet law: Collection of articles. Sverdlovsk, 1537. (in Russian).

Черданщев А.Ф. Правовое регулирование и конкретизация права // Применение советского права: Сборник статей. Свердловск, 1974. С. 15-37.

Efremova, T.F. (2000) Novyi slovar' russkogo yazyka. Tolkovo-slovoobrazovatel'nyj. [The new dictionary of the Russian language. Interpretative and word-building]. Moscow, Russkii yazyk Publ. (in Russian).

Ефремова, Т.Ф. Новый словарь русского языка. Толково-словообразовательный. М.: Русский язык, 2000. 1232 с.

Halafjan, R.M. (2017) Ispol'zovanie mezhdunarodnyh norm v kachestve sredstva obespecheniia pravovogo kachestva normativnyh pravovyh aktov Rossiiskoi Federatsii [The use of international norms as a means of ensuring legal quality of regulatory legal acts of the Russian Federation]. Bulletin of the Institute of Legislation and Legal Information. M.M. Speransky. 1 (42), 29-37. (in Russian).

Халафян Р.M. Использование международных норм в качестве средства обеспечения правового качества нормативных правовых актов российской федерации // Вестник Института законодательства и правовой информации им. М.М. Сперанского. 2017. № 1 (42). С. 29-37.

Knut, L. (2011) Constitutional and legal protection of the right to food worldwide, available at: https://en.wikipedia.org/wiki/Framework_law. (Accessed 01 June 2020). 
Korabelnikova, Ju.L., Janin, Ju.V. (2019) The role of departmental rulemaking in state lawmaking. Academic Thought. 1 (6), 55-58. (in Russian).

Корабельникова Ю.Л., Янин Ю.В. Роль ведомственного нормотворчества в государственном правотворчестве // Академическая мысль. 2019. № 1 (6). С. 55-58.

Krokhina, Yu. A. (2001) Legislative process concerning budgetary sector in the subjects of Russian Federation. Journal of Russian Law. 5, 70-77. (in Russian).

Крохина Ю.А. (2001) Правотворчество субъектов Российской Федерации в бюджетной сфере // Журнал российского права. 2001. № 5. С. 70-77.

Lazarev, V.V. (2018) Probely v prave i puti ih ustraneniya. [Gaps in law and ways to address them]. Moscow, Norma Publ. (in Russian).

Лазарев В.В. Пробелы в праве и пути их устранения. М.: Норма, 2018. 184 с.

Poduzova, E.B. (2017) Framework Contract (Contract with Open Terms and Conditions): The First Results of the Civil Law Reform. Lex Russica. 6 (127), 116-128. (in Russian).

Подузова Е.Б. Рамочный договор (договор с открытыми условиями): первые итоги реформы гражданского права // Lex Russica (Русский закон). 2017. № 6 (127). C. $116-128$.

Polenina S.V. (1996) Zakonotvorchestvo v Rossiiskoi Federacii [Lawmaking in the Russian Federation]. Moscow, The Institute of State and Law of the Russian Academy of Sciences Publ. (in Russian).

Поленина C.B. Законотворчество в Российской Федерации. М.: Институт государства и права РАН, 1996. 146 с.

Senjakin, I. N. (2007) Federalizm kak princip rossiiskogo zakonodatel'stva. [Federalism as a principle of Russian law]. Saratov: Saratov State Academy of Law Publ. (in Russian).

Сенякин И.Н. Федерализм как принцип российского законодательства. Саратов: Саратовская гос. акад. права. 2007. 502 с.

Sivickij, V.A. (2008) Teoreticheskaya model' edinogo normativnogo pravovogo (mnogostupenchatogo) akta kak sposoba konkretizacii norm sily zakona [Theoretical model of a unified normative legal (multistage) act as a way to concretize the rule of law]. Specification of legislation as a technical and legal method of rule-making, interpretive, law enforcement practice: Materials of the International Symposium (Gelendzhik, September 27-28, 2007). Nizhny Novgorod: Nizhny Novgorod Academy of the Ministry of Internal Affairs of Russia. 172-128. (in Russian).

Сивицкий B.A. Теоретическая модель единого нормативного правового (многоступенчатого) акта как способа конкретизации норм силы закона // Конкретизация законодательства как технико-юридический прием нормотворческой, интерпретационной, правоприменительной практики: Материалы Международного симпозиума (Геленджик, 27-28 сентября 2007 года). Нижний Новгород: Нижегородская академия МВД России. 2008. С. 172-188.

Strashun, B.A. (ed.) (2000) Konstitucionnoe (gosudarstvennoe) pravo zarubezhnyh stran. [Constitutional (state) law of foreign countries]. General Part. Moscow, BEK Publ. (in Russian). Конституционное (государственное) право зарубежных стран. Часть общая. Отв. ред. Страшун Б.А. М.: БЕК, 2000. 784 с.

Suharev, A.Ja., Krutskih, V.E. (eds.) (2002) Bol'shoi juridicheskii slovar' [Big law dictionary]. Moscow, INFRA-M Publ. (in Russian).

Большой юридический словарь. Под ред. Сухарева А.Я., Крутских В.Е. 2. изд, перераб. и доп. М.: ИНФРА-М, 2002. 703 с.

Symanyuk, N.V. (2014) Evolution and Forms of the Constitutional-Law Regulation of the Procedure of Distribution of Jurisdictions in the Federal Systems of Russia and Germany. Russian Law: education, practice, researches. 2 (83), 108-113. (in Russian). 
Сыманюк Н.В. Эволюция и формы конституционно-правового регулирования порядка распределения компетенции в федеративных системах России и Германии // Российское право: образование, практика, наука. 2014. № 2 (83). С. 108-113.

Tikhomirov, Yu.A. (2002) International law acts: nature and methods of influence. Journal of Russian Law. (1), 101-111. (in Russian).

Тихомиров Ю.А. Международные правовые акты: природа и способы влияния // Журнал российского права. 2002. № 1. С. 101-111.

Tikhomirov, Yu.A., (2015) Metodologija analiza i ocenki riskov v zakonodatel'noj dejatel'nosti. [Methodology of analysis and risk assessment in legislative activity]. Legal Technology. 9, 49-52. (in Russian).

Тихомиров Ю.А. Методология анализа и оценки рисков в законодательной деятельности // Юридическая техника. 2015. № 9. С. 49-52.

Tikhomirov, Y.A., Rafalyuk, E.E., Khludeneva, N.I. (eds.), (2014) Legal models and reality: monograph. O.A. Akopyan, N.V. Vlasova, S.A. Gracheva etc; Moscow, Institute of Legislation and Comparative Law under the Government of the Russian Federation: INFRA-M Publ. (in Russian).

Правовые модели и реальность: монография / О.А. Акопян, Н.В. Власова, С.А. Грачева и др.; отв. ред. Ю.А. Тихомиров, Е.Е. Рафалюк, Н.И. Хлуденева. М.: Институт законодательства и сравнительного правоведения при Правительстве Российской Федерации: ИНФРА-М, 2014. XIV. 280 с.

Tolstik, V.A. (2008) K voprosu o zavisimosti mezhdu stepen'yu konkretizacii norm prava i ierarhiei istochnikov prava [On the issue of relationship between degree of concretization of the norms of law and hierarchy of sources of law]. Specification of legislation as a technical and legal method of rule-making, interpretive, law enforcement practice: Materials of the International Symposium (Gelendzhik, September 27-28, 2007). Nizhny Novgorod: Nizhny Novgorod Academy of the Ministry of Internal Affairs of Russia. 117-126. (in Russian).

Толстик B.A. К вопросу о зависимости между степенью конкретизации норм права и иерархией источников права // Конкретизация законодательства как техникоюридический прием нормотворческой, интерпретационной, правоприменительной практики: Материалы Международного симпозиума (Геленджик, 27-28 сентября 2007 года). Нижний Новгород: Нижегородская академия МВД России. 2008. C. $117-126$.

Vengerov, A.B. (1970) Konstitucionnyi kontrol' v SSSR [Constitutional control in the USSR]. Jurisprudence. 3. 32-35. (in Russian).

Венгеров А.Б. Конституционный контроль в СССР // Правоведение. 1970. № 3. C. $32-35$.

Vlasenko, N.A. (2008) Konkretizaciya v prave: priroda i puti issledovaniya. Konkretizaciya zakonodatel'stva kak tehniko-juridicheskij priem normotvorcheskoj, interpretacionnoj, pravoprimenitel'noj praktiki: Materialy Mezhdunarodnogo simpoziuma [Concretization in law: the nature and ways of research. Concretization of legislation as a technical and legal technique of norm-setting, interpretation, law enforcement practice]. Materials of the International Symposium (Gelendzhik, September 27-28, 2007). Nizhny Novgorod, Nizhny Novgorod Academy of the Ministry of Internal Affairs of Russia. 57-68. (in Russian).

Власенко Н.A. Конкретизация в праве: природа и пути исследования. Конкретизация законодательства как технико-юридический прием нормотворческой, интерпретационной, правоприменительной практики // Конкретизация законодательства как технико-юридический прием нормотворческой, интерпретационной, правоприменительной практики: Материалы Международного симпозиума (Геленджик, 27- 
28 сентября 2007 года). Нижний Новгород: Нижегородская академия МВД России. 2008. C. 57-68.

Vlasenko, N.A. (2013) Uncertainty in law: nature and forms of expression. Journal of Russian Law. 2 (194), 32-44. (in Russian).

Власенко Н.А. Неопределенность в праве: природа и формы выражения // Журнал российского права. № 2 (194). 2013. С. 32-44.

Vlasenko, N.A. (2014) Concretization in Law: Methodological Basics of Research. Journal of Russian Law. 7 (211), 60-75. (in Russian).

Власенко Н.А. Конкретизация в праве: методологические основы исследования // Журнал российского права. № 7 (211). 2014. С. 60-75.

Vlasenko, N.A. (2014) Razumnost' i opredelennost' v pravovom regulirovanii. [Reasonableness and certainty in legal regulation]. Moscow. INFRA-M Publ. (in Russian).

Власенко Н.A. Разумность и определенность в правовом регулировании. Москва: ИНФРА-М. 2014. 154 с.

Voplenko, N.N. (1976) Oficial'noe tolkovanie norm prava [The official interpretation of the rule of law]. Moscow, Yuridicheskaya literature Publ. (in Russian).

Официальное толкование норм права / Вопленко Н.Н. М.: Юрид. лит, 1976. 118 с.

Zaloilo, M.V. (2019) Anticipatory nature of law-making and the problem of synchronization of legal regulation. Journal of Russian Law. (9), 20-29. (in Russian).

Залоило M.В. Опережающий характер правотворчества и проблема синхронизации правового регулирования // Журнал российского права. 2019. № 9. С. 20-29.

Zaloilo, M.V. (2014) Limits and technique of concretization of legal rules in lawmaking. Journal of Russian Law. (11), 34-41. (in Russian).

Залоило M.B. Пределы и техника конкретизации юридических норм в правотворчестве // Журнал российского права. 2014. № 11. С. 34-41.

Zaloilo, M.V. (2012) Law-enforcement Concretization of legal norms. Journal of Russian Law. (8), 50-56. (in Russian).

Залоило М.В. Правоприменительная конкретизация юридических норм // Журнал российского права. 2012. № 8. С. 50-56.

\section{About the author:}

Xenia Dovgan - Candidate of Legal Sciences, Associate Professor, Academy of Labor and Social Relations; 119454, Moscow, st. Lobachevsky, 90

ORCID ID: 0000-0003-4614-1936

e-mail:dok2122@bk.ru

\section{Об авторе:}

Довгань Ксения - кандидат юридических наук, доцент, Академия труда и социальных отношений; 119454, г. Москва, ул. Лобачевского, д. 90

ORCID ID: 0000-0003-4614-1936

e-mail:dok2122@bk.ru 